\title{
Human Rights Pragmatism and Human Dignity
}

David Luban

Georgetown University Law Center, luband@law.georgetown.edu

This paper can be downloaded free of charge from:

https://scholarship.law.georgetown.edu/facpub/1317

http://ssrn.com/abstract=2394233

David Luban, Human Rights Pragmatism and Human Dignity, in PHILOSOPHICAL FOUNDATIONS OF HUMAN RIGHTS, (Massimo Renzo, Rowan Cruft, \& Matthew Liao, eds., Oxford University Press forthcoming)

This open-access article is brought to you by the Georgetown Law Library. Posted with permission of the author. Follow this and additional works at: https://scholarship.law.georgetown.edu/facpub

Part of the Human Rights Law Commons, International Law Commons, and the Jurisprudence Commons 


\title{
HUMAN RIGHTS PRAGMATISM AND HUMAN DIGNITY
}

\author{
David Luban
}

Forthcoming in Philosophical Foundations of Human Rights, Massimo Renzo, Rowan Cruft, \& Matthew Liao, eds., Oxford University Press (revised draft, 28 December 2013)

\section{Human rights foundationalism and human rights pragmatism}

There is a line of argument that I will label human rights foundationalism that runs as follows: human rights are, first and foremost, rights that flow from the fact that we are human. Call them, as Allen Buchanan does, "moral human rights." Whatever features of our humanity give rise to moral human rights lie at the foundation of human rights.

Therefore, philosophical inquiry into those features is an investigation into the moral and philosophical foundations of human rights. Because people of all nations share their humanity, moral human rights are universal human rights, exactly as the title of the Universal Declaration of Human Rights (UDHR) implies. And the reason they are international is straightforward: they're universal.

An important part of human rights foundationalism is the claim that legal human rights should track moral human rights. This is what Buchanan calls the "Mirroring View," which he rejects. According to the Mirroring View, universal human rights flowing from moral rights should be codified in legal human rights instruments; conversely, codified human rights disconnected from moral rights don't belong in the canon. The codifiers got it wrong; they included more rights in their proposals than foundational inquiry can justify. Such overinclusiveness is not harmless error, because rights inflation devalues the currency of human rights.

\footnotetext{
${ }^{1}$ Allen Buchanan, "Why International Legal Human Rights?”, this volume.
} 
Buchanan, as I read him, has no objection to philosophical inquiry into universal moral rights. But he rejects the Mirroring View. So do I. Further, Buchanan implicitly disagrees with another important step in the foundationalist argument: the seeminglyobvious move from universal human rights to international human rights. Making human rights international is not simply a recognition of their universality. Buchanan offers several cogent reasons why internationalizing human rights can be an excellent idea whether or not they mirror moral human rights; and their universality (or, as he puts it, their non-parochialism) is only one of the reasons he details. I agree with this point as well.

I would put Buchanan's point this way. Making human rights international is a political decision to make them the business of the international community. It is a jurisdictional decision about which institutions will define, codify, monitor, and enforce human rights. It is the international equivalent of the domestic decision to delegate a certain set of rights to the national rather than provincial government in a federal system.

This decision is partly a matter of political-philosophical commitments: localism or globalism? Nationalism or internationalism? Trust or mistrust of "big government" transnational institutions run by elites in New York, Brussels, Strasbourg, The Hague, and Geneva? But it is also a matter of relative institutional competence. As Buchanan notes, domestic protection of constitutional rights often fails. This can result from state incapacity, in weak states or even in strong states with anemic or understaffed rule of law institutions. ${ }^{2}$ It can also happen out of state malice, because the state itself is violating the rights.

\footnotetext{
${ }^{2}$ For example, Turkish observers sometimes attribute Turkey's fragile rule of law and human rights environment to the small size and vulnerability of the legal profession. Turkey, notwithstanding its powerful state, has only a third the number of lawyers as the United Kingdom, even though Turkey is larger; furthermore, the Turkish bar has been embattled for political reasons. So too, in 2012 China had only 220,000 licensed lawyers - a third the number of practicing lawyers as the United States- to serve a population more than four times the size of the United States, which itself suffers from unavailability of legal services to low-income people. The ready availability of private legal services is
} 
The fact that domestic rule of law institutions often fail to protect constitutionalized human rights does not by itself show that international institutions will succeed, or even bring about marginal improvements. But they might be able to do so. For example, Buchanan rightly argues that international legal human rights can provide a textual and interpretive template for domestic courts and legislatures to use, in effect a public good that is available off the shelf for states to adopt. International rights can also provide ammunition for local NGOs and activists to organize and pressure their governments, even when outside pressure cannot be brought to bear. Although Buchanan does not mention it, I would add that international human rights institutions and NGOs can and do provide material resources to support human rights in developing states, including rule-of-law expertise, training, money, monitoring, and networking. Similarly, the fact that legal human rights have been internationalized can provide a legal and political rationale for wealthy states to include material resources for human rights protection in their foreign aid; in some cases donor states' domestic law require them to condition their foreign aid on human rights improvements.

When I say that internationalizing human rights makes them the business of the "international community," the phrase does not refer only to the collective sentiment of humanity (the "conscience of humanity"), as when we say that some atrocity shocks the international community. Nor does it mean only the society of states, understood as legal persons who are the formal subjects of international law. Rather, the international community is a network of concrete institutions, including states, NGOs, and international organizations. Most important is the U.N. system, with its many agencies, together with the

directly connected with the rule of law and therefore to domestic enforcement of human rights. See David Luban, "¿Existe el derecho humano a un abogado?," in Cristina García Pascual, ed., El Buen Jurista. Deontología del Derecho (Valencia: Editorial Tirant Lo Blanc, 2013), pp. 217-32. 
alphabet soup of spin-offs and quasi-independent bodies created through international treaties: WHO and WTO, UNHCR and ILO and OPCW, the many international tribunals (the International Court of Justice, the criminal tribunals, the arbitral tribunals, the WTO appellate body). The international community in this institutional sense also includes leading civil society organizations such as the International Committee of the Red Cross and Amnesty International. Importantly enmeshed in the network constituting the international community are the officially designated human rights institutions: the UN's Human Rights Committee, the European Court of Human Rights, the Inter-American Commission, the African Commission and Court, the ILO (focusing specifically on labor rights), and others.

Although Buchanan does not cast his argument explicitly in these terms, it seems to me that it makes the most sense under this institutional understanding of the international community: he is talking principally about the practical effects of legalizing human rights and making them the institutional business of international institutions.

This takes us to a second key point in Buchanan's argument: the central importance of turning international human rights into legal rights. Buchanan’s phrase “international legal human rights" (ILHR) denotes a proper subset of codified international human rights. Not all international human rights, including rights codified in international instruments, are legal. Recall that the UDHR was specifically designed as a legally non-binding declaration, out of concern that states were not at that point prepared to bind themselves legally to anything so demanding and so ambitious. So the UDHR represents a category of codified international non-legal human rights. ${ }^{3}$

\footnotetext{
${ }^{3}$ Some jurists and publicists believe that the UDHR has now become part of customary international law; others contest this. But even those who think it is part of customary international law would not ground a legal claim against a state solely on the UDHR; rather, it would be invoked to buttress, and perhaps interpret, some rights claim that is also found in a binding treaty, constitution, or other hardlaw instrument.
} 
Legalizing international human rights is a promising strategy. It makes them more comprehensible to most people, who may not know what a human right is in the abstract, but do know (in a commonsense way) what legal rights are. Legalizing international human rights also places them in the same ontological category as domestic legal and constitutional rights. By doing so, it converts human rights claims into the working currency of judicial and legislative institutions. This, like the decision to internationalize human rights, is a jurisdictional choice about which institutions will make human rights their business. Buchanan's ILHRs are legal rights that are the international community's institutional business, but also the business of domestic courts and legislatures. In effect, by legalizing international human rights the international community deputizes domestic courts and legislatures to help enforce them. ${ }^{4}$

In short, as I read Buchanan's argument, he offers an institutional view of international legal human rights, in place of the Mirroring View. It is a powerful, plausible, and sympathetic argument.

How does all this bear on human rights foundationalism? Viewing matters in this institutional manner decouples ILHRs from their supposed moral foundations, and puts Buchanan in the company of those such as Charles Beitz who deny that international human rights needs any foundation other than the ongoing practice of human rights itself. ${ }^{5}$ This is a broadly pragmatist approach, in the philosophical sense of the term in which, methodologically, theory answers to practice rather than the other way around. To put it linguistically, the semantics of terms like "human rights" and "international human rights"

\footnotetext{
${ }^{4}$ This paragraph represents my own view; Buchanan does not offer these arguments, although I expect he would agree with them.

${ }^{5}$ Charles R. Beitz, The Idea of Human Rights (Oxford University Press, 2011). Buchanan's criticism of Beitz for neglecting the General Justification Question is not, I think, a criticism of Beitz's antifoundationalism, with which Buchanan agrees.
} 
must answer to their pragmatics, their use. Their meaning is their use, and philosophical theory should limit itself to slight regimentation of the language of human rights practice without pretending that the practice must answer to it.

I agree with this way of proceeding. And I also agree with Buchanan's point that there are cogent practical and moral reasons to legalize and internationalize human rightsreasons independent of the Mirroring View and, more generally, of foundationalist theory. In my view, his paper gets this exactly right, and he significantly enhances our understanding of why human rights should be legalized and internationalized.

In my concluding section, though, I shall resurrect a form of foundationalism within a fundamentally pragmatist framework. As I next argue, without some connection between ILHRs and moral human rights, Buchanan's pragmatist defense of ILHRs will not work.

\section{Why Buchanan's defense of ILHRs still requires a connection with moral human rights}

The reason is that without a connection with moral human rights, ILHRs will fail as legal rights. So, even on its own terms, a pragmatist and institutional argument cannot throw ILHRs' theoretical connection with moral rights overboard, as excess baggage. Let us see why. I present the argument in four steps.

Step 1. One perpetual embarrassment that ILHRs have always faced is the lack of effective institutions to enforce them. Sometimes, for jurisdictional or political reasons, international human rights claims cannot be adjudicated. For example, the European Court of Human Rights has held that the European Convention on Human Rights' jurisdiction does not include a military adversary's territory. ${ }^{6}$ Sometimes, the adjudicatory bodies have no

\footnotetext{
${ }^{6}$ Bankovic and Others v. Belgium and 16 Other Contracting States, 2001-XII Eur. Ct. H.R. 333 (Grand Chamber), 123 ILR 94, \$S59-63 (holding that relatives of civilians killed in NATO bombing of a Belgrade television station have no cause of action for violation of human rights under the
} 
authority to enforce their decisions and orders. When the United States ratified the International Covenant on Civil and Political Rights (ICCPR), the U.S. Senate attached a reservation declaring that ICCPR's substantive articles are not self-executing, which means that no cause of action can arise under them in U.S. courts unless Congress implements them through legislation (which it has no intention of doing). ${ }^{7}$ In addition, the United States declined to join the First Optional Protocol to the ICCPR, which would authorize the UN's Human Rights Committee to hear complaints against the U.S. So, even though the ICCPR is a binding treaty that creates legal rights_ — unlike the non-binding UDHR_-and the United States ratified ICCPR, no judicial body inside or outside the country is empowered to adjudicate complaints about U.S. human rights violations.

For that matter, even if the United States had permitted the Human Rights Committee to accept complaints against it, the Committee lacks enforcement powers: all it can do about complaints is call them to the attention of a state. So too, only 20 of 35 American states have accepted the mandatory jurisdiction of the Inter-American Court of Human Rights. The African Court of Human Rights likewise lacks mandatory jurisdiction. Regrettably, the European Court of Human Rights is the only human rights court in the world that actually has robust enforcement powers. Finally, even if international tribunals have the legal authority to order a remedy, they may lack the power to impose their will if a state defies them—consider the ICC's current inability to arrest its Sudanese suspects.

Call this the problem of enforcement deficit.

Convention, because the ECHR's jurisdiction does not extend to the territory of a military adversary that is not party to the Convention).

7 U.S. reservations, declarations, and understandings, International Covenant on Civil and Political Rights, 138 Cong. Rec. S4781-01 (daily ed., April 2, 1992), available at http://www1.umn.edu/humanrts/usdocs/civilres.html, III(1). 
Step 2. This enforcement deficit makes the ILHRs contained in most of the world's human rights instruments legal rights without legal remedies. Admittedly, legal rights without legal remedies are not conceptually impossible. And they occasionally crop up even in mature and effective domestic legal systems. ${ }^{8}$

I note that legal realists sometimes deny as a conceptual matter that rights without remedies are genuine rights. That is because they equate law with its practical consequences (in Holmes's terms, they view law from the point of view of the Bad Man "who cares only for the material consequences"9). That this is a weak argument has been recognized since H. L. A. Hart's critique of realism in The Concept of Law. But this much of the realist argument seems right: rights without remedies must be the rare exceptions, not the rule, or else it makes little sense to call them legal rights. A self-styled legal system in which rights without remedies are common, rather than anomalous, would not do what legal systems do, namely provide a framework for organizing human action. It would be a legal system in name only. ${ }^{10}$

\footnotetext{
${ }^{8}$ A rights violation might occur outside the territorial jurisdiction of any court; or the court may lack the legal authority to order the political branches of government to provide a remedy; or, in the case of treaty-based rights, the violated individual may not be authorized to take a rights infringement to court unless her home state does so on her behalf, which for diplomatic reasons it may decline to do. None of these are imaginary scenarios: all have occurred in recent U.S. practice. In Maqaleh v. Gates, 605 F.3d 84 (D.C. Cir. 2010), the court found that it has no jurisdiction over habeas corpus in the U.S. prison camp at Baghram, Afghanistan. The same court found that it lacks authority to order the release of a Guantánamo inmate within U.S. territory even though the detainee had won his habeas case, because the political branches of government, not the courts, have plenary authority over immigration. Kiyemba v. Obama, 605 F.3d 1046, 1048 (D.C. Cir. 2010). In an earlier case, that court held that violations of a detainee's Geneva Convention rights are non-justiciable, because the injured party in a treaty breach is not the violated individual but his state. Hamdan v. Rumsfeld, 415 F.3d 33 (D.C. Circ. 2005). So too, only states can bring cases to the ICJ, so U.S. breaches of individual consular rights of Mexicans, Paraguayans, and Germans had to be brought by their home states. ${ }_{9}^{9}$ Oliver Wendell Holmes, Jr., “The Path of the Law," Harvard Law Review 10 (1897): 459.

${ }^{10}$ In Lon Fuller's terminology, a system-wide failure of congruence between the law in books and the law as it is enforced is simply a failure to make law. Lon L. Fuller, The Morality of Law, rev. ed. (New Haven, CT: Yale University Press, 1969), chapter 2.
} 
And that spells trouble for the system of international legal human rights, where non-justiciability, legal non-enforceability, or toothless enforceability are no anomaly. They are the rule, not the exception.

Call this the problem of rights without remedies.

Step 3. Everyone involved with human rights practice understands that international human rights are radically underenforced and unenforceable. The most common response (both in theory and practice) is the argument that the primary enforcer of international human rights, non-legal as well as legal, is the so-called "mobilization of shame." the mobilization comes from the outside world or, as Buchanan rightly emphasizes, from domestic activists using ILHRs as an organizing tool, shame sanctions, bad publicity, and international outrage are the principal remedial scheme that human rights practice has to offer for state violations of ILHRs. Without any such remedial practice, I have argued, there is nothing legal about a system of international human rights - they may be IHRs, but they are not $\underline{I L H R s .}$

Call this the problem of generating international outrage.

Step 4. How is the mobilization of shame going to come about? Only, it seems to me, if ILHRs matter to people morally, and to a degree that sets ILHRs off from less significant legal rights (say, from the legal right to paint my house yellow). That means ILHRs cannot be decoupled from moral human rights, although they almost certainly can be decoupled from any specific philosophical theory of moral human rights. If legal human rights are just another bit of positive law, then why should anyone invest time and money, let alone risk their lives, to mobilize around ILHRs? Why should state leaders (pretend to) feel ashamed

${ }^{11}$ See Robert F. Drinan, S.J., The Mobilization of Shame: A World View of Human Rights (New Haven, CT: Yale University Press, 2001). Drinan borrows the title phrase from Amnesty International. See also Beth A. Simmons, Mobilizing for Human Rights: International Law in Domestic Politics (New York: Cambridge University Press, 2009). 
about violating them, any more than they feel ashamed about violating technical regulations about the size and shape of cartons in international shipping?

The moral specialness of human rights is reflected in legal doctrine. Consider this well-known dictum in the European Court of Human Rights' Soering decision:

In interpreting the Convention regard must be had to its special character as a treaty for the collective enforcement of human rights and fundamental freedoms. Thus, the object and purpose of the Convention as an instrument for the protection of individual human beings require that its provisions be interpreted and applied so as to make its safeguards practical and effective. ${ }^{12}$

The Court therefore uses the so-called Principle of Effectivity to interpret clauses of the Convention broadly rather than literalistically. And it does so because it recognizes that there is something special about human rights and fundamental freedoms, lending special urgency to making them effective, and counseling against narrow, crabbed, or niggling modes of interpretation.

Let me put the point about the moral specialness of human rights another way. Whatever its other infirmities, human rights foundationalism has an answer to the question "why do you call these things 'buman rights'?" The foundationalist answer is that they are moral claims every human being is entitled to make, where the entitlement and the content of the claims flows from our human status itself. But if ILHRs are positive law with no necessary connection with human status, then there is no particular reason to dignify them with the label "human rights." We could delete the word "human" from the label without doing any conceptual damage, because it does no definitional work. Indeed, if Buchanan is right in rejecting the Mirroring View, deleting the word "human" might avoid confusion. We

12 Soering v. United Kingdom, 161 Eur. Ct. H.R. 87 (1989), reprinted in 28 I.L.M. 1066, 1091-1092 (1989), $₫ 87$. 
could then give international human rights a more technical name, maybe "transnational legal claim rights," without losing any conceptually definitive feature.

But obviously no organization called Transnational Legal Claim Rights Watch, or Transnational Legal Claim Rights First, will spring into existence to mobilize shame around their violation. And this is not simply a point about the rhetorical force of labels. It is a point about the moral importance of these rights, the fact that we place great moral weight on them, because we think (rightly or wrongly) that they are closely tied to something basic about humanity as such.

What is that something? The UN Charter, the UDHR, the two major human rights covenants, the Helsinki Accords, the American Convention on Human Rights, and the European Charter of Human Rights all call it "human dignity." Without pretending to know what that phrase means—-more about that soon—we can say that ILHRs are capable of mobilizing shame because they concern themselves with human dignity, not because they are legal and not because they are international.

Thus, to summarize the argument, the three problems of enforcement deficit, rights without remedies, and the need to generate international outrage require some connection between ILHRs and moral human rights. Otherwise, ILHRs will hardly count as legal rights at all. That connection to morality need not be via the concept of human dignity, but the fact that it is human dignity to which the major human rights instruments refer should recommend it to a human rights pragmatist who derives theory from the proprieties of practice. 
I don't for a moment suggest that Buchanan doubts the special moral importance of human rights. ${ }^{13}$ On the contrary, his arguments about why internationalizing them is important presuppose that human rights matter immensely. His paper aims to provide extra ammunition in the fight to implement human rights, and denying their moral importance is no doubt the furthest thing from his mind. I am likewise not suggesting that Buchanan is dismissive of human dignity.

My point is rather that in rejecting the Mirroring View, and human rights foundationalism more generally, Buchanan's paper leaves a gap in his account of how legalizing (positivizing) and internationalizing human rights is something worth doing. If ILHRs are only accidentally connected with moral human rights, then the phrase "human rights" in "international legal human rights" is merely a homonym of human rights in the moral sense-in which case the mobilization of shame appears to rest on a misunderstanding. Unfortunately, once the misunderstanding is gone, the status of ILHRs as specifically legal rights thins to the vanishing point because of the problems of enforcement deficit, rights without remedies, and generating the mobilization of shame.

And surely Buchanan agrees that the system of ILHRs must have remedies, for this point is crucial to his second argument on behalf of ILHRs: that the existence of a system of ILHRs is essential to the legitimacy of the state system (an argument with which I wholeheartedly agree). A hollow and toothless system of ILHRs cannot legitimize the state system; it can only provide a veneer of legitimacy.

\section{An illustration: human rights and IHL}

\footnotetext{
${ }^{13}$ Indeed, he insists on it in his new book The Heart of Human Rights (New York: Oxford University Press, 2013). Among other things, this book aims to plug the argumentative gap I identify here, although Buchanan's method for doing so is different from the one I offer here.
} 
Let me illustrate the phenomenon under discussion with an example drawn from Buchanan's paper: the effect of international legal human rights on the laws of warinternational humanitarian law (IHL). Buchanan argues that the development of ILHRs could stimulate progressive development in humanitarian law. I think he is right, and to a degree this has already happened. But the path is not straightforward, and it rests to a great extent not on legal developments but on the mobilization of shame described earlier.

The two bodies of law, IHL and international human rights law, have very different philosophical roots, the former originating in the Benthamite desire to reduce human suffering in war, the latter in a more Kantian notion of respect for individuals and their human dignity (although, as I shall argue later, it is a mistake to tie the notion of human dignity too closely to any philosophical theory including Kant's). The humanitarian impulse to temper war's cruelty is ancient-it can be found in the Seven Military Classics of ancient China as well as in western texts as far back as Cicero and even the Iliad. But IHL in its contemporary form did not really launch until the mid-19 $9^{\text {th }}$ century with the formation of the International Committee of the Red Cross; international human rights law of course began much later, after World War II.

While Buchanan is correct that human rights thinking has very much shaped modern IHL, his chronology is not entirely accurate; modern IHL did not wait on the emergence of human rights law. The Geneva Conventions of 1949 already contain what is rightly called a mini-human rights convention in their common article 3. Common article 3 prohibits violence, hostage taking, outrages against personal dignity, and punishments without fair trials against "persons taking no active part in hostilities" in non-international armed conflicts. Protections are even more stringent in the rules governing international armed conflicts. It seems unlikely that the GCs in general or common article 3 in particular were 
influenced by the UDHR, which was adopted scant months before the text of the GCs was completed. But I think it is very likely that the same revulsion against the horrors of World War II lay at the root of both the GCs and the UDHR—as well as the UN Charter-and there is every reason to call it human rights thinking.

Buchanan is likewise mistaken that "rape was recognized as a violation of international legal human rights long before it was seen to fall within the scope of war crimes." Mass rape, particularly rapes committed in the Nanjing massacres, was a central concern of the 1946 Tokyo Tribunal. ${ }^{14}$ And the law the allies imposed on occupied Germany, so-called Allied Control Council Law No. 10, explicitly named rape as a crime against humanity.

So it isn't quite right that the regime of international legal human rights pre-dated human rights protection in IHL; but it is likely that human rights thinking influenced both. As human rights law continued to develop, its impact on IHL has been unmistakeable. Theodore Meron labels it the "humanization of humanitarian law," and Gabriella Blum calls it the "individualization of war." "15 Both authors mean not only the evolution of ever greater humanitarian protections in IHL, but also a gradual move toward regarding those protections as rights of the protected individuals and not of their states or collectivities. That is a remarkable change, for more than any other human activity, war collectivizes, whereas human rights law individualizes.

\footnotetext{
${ }^{14}$ See, e.g., Kelly Dawn Askin, War Crimes Against Women: Prosecution in International War Crimes Tribunals (Martinus Nijhoff, 1997), pp. 180-81. Notably, Japanese cabinet minister Koki Hirota was executed for failing to intervene in the government to halt the "rape of Nanking," a rare example of draconian punishment of a civilian under a theory of command responsibility. Of course, rapes were not the only atrocities committed in Nanjing, but they were salient and notorious.

15 Theodore Meron, "The Humanization of Humanitarian Law," American Journal of International Law 94 (2000): 239-78; Gabriella Blum, "The Individualization of War: From War to Policing in the Regulation of Armed Conflicts," in Austin Sarat et al. eds., Law and War (Stanford University Press, forthcoming), available on SSRN at http://ssrn.com/abstract=2231168. Meron dates the change to the 1968 Tehran Conference and a pair of 1970 UN Secretary General reports.
} 
Earlier, I mentioned the European Court of Human Rights' Soering decision as an example of human rights-oriented legal interpretation—anti-formalist and grounded in the view that human rights are special enough to deserve broad, effectiveness-based reading. A strikingly parallel example in humanitarian law comes from the ICTY's first major case, Tadić, where the Appeals Chamber resolved a knotty legal issue by resorting to the same interpretive approach as in Soering. The judgment explained that one of its conclusions, which has little support in the statutory text,

is borne out by the entire logic of international humanitarian law. This body of law is not grounded on formalistic postulates.... Rather, it is a realistic body of law, grounded on the notion of effectiveness and inspired by the aim of deterring deviation from its standards to the maximum extent possible. ${ }^{16}$

So the "entire logic of international humanitarian law" runs strictly parallel to the logic of human rights law, elevating effectiveness and broad protection over strict interpretation of legal instruments. As the ICTY put it in its Furundrija judgment,

The essence of the whole corpus of international humanitarian law as well as human rights law lies in the protection of the human dignity of every person.... The general principle of respect for human dignity is ... the very raison d'etre of international humanitarian law and human rights law; indeed in modern times it has become of such paramount importance as to permeate the whole body of international law. ${ }^{17}$

The humanization of humanitarian law is still very much a work in progress.

Unsurprisingly, the human rights orientation of humanitarian law is most prominent in the law of belligerent occupation, where hot combat is the exception and the occupying forces

16 Prosecutor v. Tadić, Judgement, Case No. IT-94-1-A, Appeals Chamber, 15 July 1999, $₫ 96$.

${ }^{17}$ Prosecutor v. Furund₹ija, Judgment, Case No. IT-95-17/1-T, T.Ch. II, 10 December 1998, para. 183. 
must assume at least limited governance functions. ${ }^{18}$ In occupations, the issue of whether the law of war or the law of peace should apply is maximally unclear. The ICJ has held that the "protection of the [ICCPR] does not cease in times of war,"19 which suggests that human rights law always predominates. But the ICJ adds that the law of war, as lex specialis (special law), defines the meaning of human rights in wartime. A killing that would be arbitrary in peacetime might not be so on the battlefield. This means that in practice, human rights protections in wartime can be no broader than the protections in IHL (at least on matters that both of them address). But are belligerent occupations wartime or peacetime events? Increasingly, the answer has been "peacetime." I noted earlier that the European Court of Human Rights declared that the European Convention on Human Rights does not apply on enemy territory in armed conflict; but in a 2011 opinion, the Court extended its jurisdiction to areas of Iraq under effective control of the British military. ${ }^{20}$ Judge Bonello's concurring opinion excoriated the UK for arguing that applying the Convention in Iraq would be human rights imperialism:

It ill behooves a State that imposed its military imperialism over another sovereign State without the frailest imprimatur from the international community, to resent the charge of having exported human rights imperialism to the vanquished enemy. ${ }^{21}$ Similarly, the International Court of Justice invoked human rights instruments when it declared Israel's separation barrier illegal. ${ }^{22}$

\footnotetext{
${ }^{18}$ For an overview, see Eyal E. Benvenisti, The International Law of Occupation, 2nd ed., (Oxford: Oxford University Press, 2012).

${ }^{19}$ Legality of the Threat or Use of Nuclear Weapons, Advisory Opinion, I.C.J. Reports 1996, at 226, para. 25.

20 Al-Skeini and Others v. United Kingdom, Application no. 55721/07, Council of Europe: European Court of Human Rights, 7 July 2011, available at:

http://www.refworld.org/docid/4e2545502.html [accessed 21 October 2013]

${ }^{21}$ Ibid., separate opinion of Judge Bonello, $\mathbf{9} 37$. He adds: "At my age, it may no longer be elegant to have dreams. But that of being branded in perpetuity a human rights imperialist, I acknowledge sounds to me particularly seductive." $\mid 39$.
} 
At the same time, however, militaries and military lawyers have pushed back hard against humanization and individualization in "hot" situations of combat. When the ICRC declared that militaries must not kill civilians who directly participate in hostilities if they can be captured — a human rights standard — several military law experts on the ICRC's advisory panel dissented and refused to sign, on the ground that humanitarian law has never prohibited soldiers from killing enemies who have not surrendered. ${ }^{23}$ And, notably, the U.S. government has strongly resisted legal arguments that its drone program constitutes extrajudicial assassination - a human rights concept that, the government argues, is wholly inapplicable to targeting enemy combatants in a war.

And yet, in May 2013, the Obama administration issued a policy on drone strikes that includes a preference for capture over killing, and "near certainty that non-combatants will not be injured or killed." ${ }^{24}$ In other words, after arguing for years that human rights law does not apply on the battlefield, the U.S. government's declared policy now mirrors the requirements of human rights law. Why?

The answer seems straightforward: the mobilization of shame. International and domestic anger at the United States drone strikes has increased dramatically, and seemingly drove U.S. policy in the direction of human rights.

As another example, consider the way the United States has treated in bello proportionality. This rule prohibits attacks on legitimate military targets that are anticipated

\footnotetext{
22 Legal Consequences of the Construction of a Wall in the Occupied Palestinian Territory, Advisory Opinion, 2004 I.C.J. 131 (July 9).

${ }^{23}$ For a particularly vituperative response, see W. Hayes Parks, "Part IX of the ICRC 'Direct Participation in Hostilities' Study: No Mandate, No Expertise, and Legally Incorrect," (2010) NYU Journal of International Law \& Politics 42: 769-832.

24 White House Office of the Press Secretary, "Fact Sheet: U.S. Policy Standards and Procedures for the Use of Force in Counterterrorism Operations Outside the United States and Areas of Active Hostilities," available at http://www.whitehouse.gov/the-press-office/2013/05/23/fact-sheet-uspolicy-standards-and-procedures-use-force-counterterrorism (accessed Oct. 15, 2013).
} 
to cause civilian damage excessive in relation to the military advantage-in other words, disproportionate collateral damage. In theory, that standard imposes no upper limit on the number of unintended civilian casualties, if the military advantage of an attack is great enough. And yet in practice the United States reportedly used absolute numerical caps. One former Pentagon official explained that early in the Iraq war "our number was 30. So, for example, Saddam Hussein. If you're gonna kill up to 29 people in a strike against Saddam Hussein, that's not a problem.... But once you hit that number 30, we actually had to go to either President Bush, or Secretary of Defense Rumsfeld. ${ }^{, 25}$ I have heard military officers saying that a few years later the number was ten; eventually, it approached near zero. Regardless of which number is right, it is conspicuous that no absolute numerical ceiling on civilian casualties makes conceptual sense under a proportionality standard. Clearly, the fixed numerical ceiling reflected a judgment that too many casualties would cause too much outrage, regardless of the importance of the target. The mobilization of shame strikes again. It not only enforces the law of proportionality, but reshapes its pragmatics.

Mightn't the alternative explanation of this phenomenon be more effective law enforcement mechanisms? That seems rather unlikely. The ICC has no jurisdiction over the United States, which is not a member; and the chance of the United States allowing any foreign tribunal to try U.S. forces for war crimes is for all practical purposes zero. ${ }^{26}$ The United States has no genuine fear about international legal accountability; it has substantial concerns about international outrage.

My point in this section is that the humanization of humanitarian law is incomplete

${ }^{25}$ CBS News, "Bombing Afghanistan," available at http://www.cbsnews.com/2102-18560_1623411230.html (last visited Oct. 15, 2013). There has never been an official confirmation of this assertion.

26 The U.S. Congress enacted legislation authorizing the president to use force to free any U.S. national from ICC custody. 
as a legal matter, except perhaps in belligerent occupations. But human rights thinking has the power to mobilize shame, and in that sense ILHRs have been effectuated in humanitarian law to a degree far greater than black letter law acknowledges. So, if Buchanan is right that ILHRs stimulate progressive development in humanitarian law, the reason is not institutional law enforcement; it is moral outrage, based on the sense that individual civilians have human rights that must be honored even in wartime.

\section{Human dignities}

If these reflections are correct, Buchanan's argument needs to be supplemented with an explanation of how ILHRs connect with moral human rights. If the Mirroring View is not the answer, what is?

Notice that the ICTY said that the "general principle of respect for human dignity is ... the very raison d'être of international humanitarian law and human rights law" —as if the two branches of law share a common root in human dignity. I have noted that the major human rights instruments give the same answer: human rights are essential to maintaining human dignity. Precisely because a human rights pragmatist begins with practice rather than theory, the very fact that the promotion of human dignity is the consensus answer embedded in the major human rights instruments makes it the first hypothesis to examine.

Notoriously, though, human dignity is a vague and multiply ambiguous concept, and indeed there has never been a single received analysis of it. For Cicero, who appears to have introduced the term, our dignity comes from our reason, the quality that sets us apart from beasts. ${ }^{27}$ In the biblical tradition, human dignity meant being created in God's image and

\footnotetext{
${ }^{27}$ Cicero, De Officiis 1.30.105-07. For discussion of the Ciceronian origin of the term 'human dignity', see Hubert Cancik, "Dignity of Man' and 'Persona' in Stoic Anthropology: Some Remarks on Cicero, De Officiis I 105-107," in David Kretzmer and Eckhart Klein, eds., The Concept of Human Dignity in Human Rights Discourse (Kluwer Law International, 2002), pp. 19-37. On the other hand, for Cicero 'dignity' was reserved entirely to men: "Again, there are two orders of beauty: in the one, loveliness
} 
having dominion over nature. In the Renaissance, Pico della Mirandella identified human dignity with free will, which makes man alone a "chameleon" who can "ordain for thyself the limits of thy nature." ${ }^{28}$ For Kant, as for the contemporary human rights theory of James Griffin, human dignity lies in autonomy; however, Kant and Griffin may not mean the same thing by autonomy, Kant emphasizing the power of self-legislation and Griffin the power to set one's own ends. ${ }^{29}$

To adopt any of these accounts would launch us on a project of human rights foundationalism, committing us to demonstrate how (and which) human rights derive from human dignity as analyzed in the theory. A human rights pragmatist, on the other hand, insists that the meaning of the phrase "human dignity" is not defined by a philosophical theory, but rather determined by its use in human rights practice. In a sense, the pragmatist reverses the order of explanation, defining "human dignity" by its inferential commitments rather than the other way around.

For example, when the German Constitutional Court declared that life sentences without parole (LWOP) are unconstitutional because they violate human dignity, ${ }^{30}$ a foundationalist would demand a proof that LWOP interferes with, say, autonomy in a way that a life sentence with the possibility of parole does not. The pragmatist, on the other hand, will take the material inference from the distinctive feature of LWOP (no possibility of

(venustas) predominates; in the other, dignity; of these, we ought to regard loveliness as the attribute of woman, and dignity as the attribute of man." Ibid., 1.130, pp. 131-32.

${ }_{28}$ Pico della Mirandella, "Oration on the Dignity of Man," in The Renaissance Philosophy of Man, Ernst Cassirer, Paul Oskar Kristeller, John Herman Randall Jr. eds., Elizabeth Livermore Forbes trans. (University of Chicago Press: 1948), p. 225.

${ }^{29}$ I am drawing on Kant's Formula of Autonomy, "So act that your will can regard itself at the same time as making universal law through its maxim," Foundations of the Metaphysics of Morals, 4 Ak. 434. James Griffin, On Human Rights (Oxford: Oxford University Press, 2008), p. 33 (defining autonomy as being able "to choose one's own path through life") and p. 45 (identifying autonomy with human dignity).

30 Life Imprisonment Case (1977), 45 BverGE 187, in Donald P. Kommers and Russell A. Miller, eds. \& trans., 2d ed., The Constitutional Jurisprudence of the Federal Republic of Germany 308-309 (Durham, NC: Duke University Press: 1997). 
parole) to the violation of human dignity as part of the meaning of human dignity. As the German court explained its reasoning, taking away the possibility of parole presumes that atonement and development of the criminal's personality are impossible. So too, when the Israeli Supreme Court declared that interrogating suspects through stress positions violates human dignity, that inference likewise becomes part of the meaning of human dignity. ${ }^{31}$

This is not to say that anything counts as human dignity if human rights adjudicators say it does. Human dignity is not defined by the ipse dixits of judges. Declarations like those of the German Constitutional Court and the Israeli Supreme Court need to be accepted and taken up by the relevant communities of discourse before they become part of the public meaning of the phrase; the judicial declarations require retroactive validation through uptake. This phenomenon of retroactive validation may sound mysterious, but in reality it is no different from the familiar path of the common law. Some judicial holdings become part of the common law because subsequent courts and commentators take them to be such, while other holdings do not, either getting explicitly overruled or (more commonly) simply ignored. Here, of course, the relevant community whose acceptance of a conception of human dignity matters is not limited to judges and lawyers, but to all those engaged in human rights practice. But the retroactive validation of a conception by the relevant community is analogous to the path of the common law. ${ }^{32}$

How, then, would a human rights pragmatist understand "human dignity" as it appears in the UDHR and other human rights instruments? Almost certainly, those instruments mean nothing so theoretically and culturally specific as reason, free will,

\footnotetext{
31 Public Committee Against Torture in Israel (PCATI) v. State of Israel, HCJ 5100/94 (1999), available at http://www.law.yale.edu/documents/pdf/Public_Committee_Against_Torture.pdf (visited Oct. 5, 2013), $\mid 25$.

32 Much of my account of pragmatist meaning-formation comes from Robert B. Brandom, in particular chapter 3 of Reason in Philosophy (Harvard University Press, 2009).
} 
autonomy, the imago Dei, or other familiar foundationalist conceptualizations of human dignity. If anything, their drafters deliberately chose to leave the suggestive phrase "human dignity" vague and undertheorized in order to avoid getting bogged down in metaphysical and religious debates that would derail the project of attracting worldwide assent to the UDHR. ${ }^{33}$ Some delegates at the UDHR drafting sessions wanted to include an explicit declaration that human rights come from God; the reference to "human dignity" was chosen as a less combustible alternative. Different cultures could bring whatever theoretical baggage they wished to the concept of human dignity.

This suggests that the best way of understanding what the UDHR and other human rights instruments mean by "human dignity" is simply by looking at the content of the documents. In effect, the instruments themselves catalogue the material inferences and incompatibilities that define human dignity. The rights to life, liberty, and security (article 3) are necessary to human dignity, as is the right to personhood before the law (article 6). But so are labor rights, including rights to rest and leisure, reasonable limitations of working hours, and the much-maligned right to periodic paid holidays (article 24). (As Buchanan notes, the latter is often cited as a poster child of human rights inflation by foundationalists. Apparently those who so regard it-no doubt they include academic critics writing during their sabbaticals—-have not considered seriously what a working life is like for someone whose day-to-day survival depends on a regular paycheck and who must work at a grinding job 52 weeks a year from age fifteen until premature death at fifty.)

It follows, of course, that human dignity cannot underwrite a foundationalist account that derives these particular human rights from the concept of human dignity. Given that the

\footnotetext{
33 See Johannes Morsink, The Universal Declaration of Human Rights: Origins, Drafting, and Intent (Philadelphia: University of Pennsylvania Press, 1999), pp. 284-302.
} 
meaning of human dignity is given in significant part by the catalogue of rights, any such derivation would be circular.

One last point about human dignity as the (virtual) foundation of human rights seems important: human dignity, as defined by human rights practice, is context-dependent and may consist of a family of conceptions. In the context of trial rights, for example, the right to participate through counsel focuses on presumptively having a story to tell as an aspect of what respect for human dignity means. ${ }^{34}$ Voting rights, the right to stand for public office, and the (collective) right of self-determination, understood as an individual right to live in a self-determining political community, focus on our nature as zoon politikon, being a political creature, as an aspect of human dignity. Rights as disparate as the right to education and the right not to be subjected to life imprisonment without parole focus on the development of the personality as an aspect of human dignity. The "special care and assistance" owed to "motherhood" (UDHR article 25(b)) might plausibly be understood as an assertion that childbearing and caregiving confer-contrary to ancient patriarchal beliefs-a specific form of human dignity. Labor rights assert that even the most menial occupations deserve the respect and solicitude of the larger community, and therefore assert the human dignity of the laborer. Such labor rights, like the very different right not to be subjected to degrading treatment or punishment, suggest that non-bumiliation is an important index of human dignity; I have argued that in a great many contexts non-humiliation is a commonsense surrogate for human dignity. ${ }^{35}$ And so on; what we confront, therefore, is not a unitary conception of human dignity, but a network of human dignities bearing family resemblances to each other.

\section{Virtual foundationalism}

\footnotetext{
${ }^{34}$ So I have argued in the first chapter of Legal Ethics and Human Dignity (Cambridge University Press: 2007).

35 Ibid.
} 
But anti-foundationalism isn't the whole story. It may still be that human dignity grounds human rights, even as human rights practices teach us concretely what human dignity means. In fact, that human dignity grounds human rights is precisely the essential connection between moral rights and ILHRs—-the connection that (I have argued) makes ILHRs possible.

The vocabulary of human rights is one of several moral vocabularies available to us. It seems to me that it has gained dominance in today's conversations because it carries two implications essential to the moral world we inhabit: first, that every human being should count as an object of concern, and second, that no one should have to beg for their rights. The first tells us that no human individual is merely, in Arthur Koestler's phrase, a multitude of one million divided by one million. The individual counts, and indeed all individuals count as individuals.

The second tells us that human rights aren't merely the result of grace, generosity, or charity on the part of the comfortable and powerful, for which the poor and powerless must wheedle and bow and scrape and be forever grateful. A legitimate human rights claim gives the claimant standing to issue a moral writ of mandamus demanding that third parties enforce the claim either through law or through social pressure and shaming. As such, being a bearer of human rights is a badge of self-respect, showing that the claimant is not a vassal or a supplicant.

I think the concept of human dignity brilliantly encapsulates these two foundational commitments of human rights practice. I call them "foundational" not to resurrect the Mirroring View, nor to propose an architectural distinction between basic and derived propositions in ethics, but because it is difficult to see why anyone would engage in human rights practice as we see it today without sharing these commitments. The language of 
dignity lends itself to those commitments. To talk about dignity is to talk about status and rank - the original semantic field of the concept of "dignity". The two foundational commitments, to individual worth and to rights as justified demands rather than humble beseechings, imply that every human being has high status and rank. ${ }^{36}$

So even if the content of human dignity (that is, the extension of the concept) is intellectually parasitic on human rights practice rather than the other way around, it still makes sense to claim that human dignity is the foundation of human rights. That is because the concept of human dignity condenses and expresses the two foundational commitments of human rights practice.

There is a more subtle point here as well. Wittgenstein once wrote, "The mathematical problems of what is called foundations are no more the foundation of mathematics for us than the painted rock is the support of a painted tower." ${ }^{37}$ Wittgenstein means two things by this very canny metaphor. First, of course, is that the painted tower would not fall off the canvas if the painted rock were erased. In that sense, the foundationrelation is an illusion, and Wittgenstein's aphorism is typically read as an anti-foundationalist claim that mathematics needs no foundation beyond the practices of mathematicians. I agree with this reading, which bears a resemblance to what I have been arguing about human rights_ - and what I take Buchanan to accept as well, inasmuch as he rejects the Mirroring View.

\footnotetext{
36 There is a seeming paradox here: if "dignity" is a status-and-rank concept, it presupposes hierarchy and not equality. But contemporary human rights discourse insists not only on human dignity, but on equal human dignity. The paradox is only seeming, however. When egalitarianism replaces an earlier rank-and-status, caste, or aristocratic system, societies can either equalize down or equalize uptreating everyone as the lowest were treated in the ancien régime, or treating everyone as an aristocrat. The conception of equal human dignity in human rights instruments is a commitment to equalizing up. I take the distinction from James Q. Whitman, Harsh Justice: Criminal Punishment and the Widening Divide Between Punishment in America and Europe (OUP: 2005).

${ }^{37}$ Ludwig Wittgenstein, Remarks on the Foundations of Mathematics, G.H. von Wright et al. eds., G.E.M. Anscombe trans., rev. ed. (Cambridge, MA: MIT Press: 1978), p. 171e.
} 
However, Wittgenstein had another point. There is no denying that the picture would look surreal if the tower simply floated Magritte-style in mid-air, and in that sense the painted rock provides necessary verisimilitude—necessary not in the sense that the rock is holding up the tower, but in the sense that without it the picture would portray something quite different. Within the picture, the rock is indeed the foundation for the tower, and the question "What's the tower resting on in Van Gogh's The Old Tower?" is perfectly cogent. That, too, I take it, is part of Wittgenstein's point. In the same way, even if human rights practice can exist without a philosophical derivation of human rights from human dignity, human dignity serves as the "virtual" foundation of human rights in the sense that the painted rock is the virtual foundation of the painted tower: those who engage in human rights practice share the foundational commitments captured by the language of human dignity. That connection is the mobilizer of shame and the motor of ILHRs. 